\title{
Pityriasis rubra pilaris
}

\section{Pityriasis rubra pilaris}

\section{GÓDOR FERENC DR., HÁRSING JUDIT DR., WIKONKÁL NORBERT DR., KÁRPÁTI SAROLTA DR.}

\author{
Semmelweis Egyetem Általános Orvostudományi Kar Bôr-, Nemikórtani és \\ Bőronkológiai Klinika, Budapest
}

\section{ÖSSZEFOGLALÁS}

A pityriasis rubra pilaris egy ritka, ismeretlen eredetû, krónikus papulosquamosus börbetegség. Jellemzóen felnöttkorban jelentkezik, de gyermekkori formája is ismert. Jellegzetessége a follicularis hyperkeratosis, a tünetmentes bőrszigeteket magába foglaló, hámló, narancsvörös, viszkető dermatitis, amely erythrodermáig súlyosbodhat. Etiológiája mindmáig nem pontosan tisztázott. Hátterében A-vitamin hiány, felsô légúti betegség, HIV fertôzés szerepét feltételezik, ugyanakkor familiáris esetek is elófordulnak. Ritka elófordulása miatt gyakran fel nem ismert kórkép. A kezelés elsödleges vonalát a szisztémás retinoidok képzik, ezek közül is elsósorban az acitretin, de rendszeresen találkozunk erre nem reagáló esetekkel is.

A szerzók egy 59 éves beteg esetét ismertetik, akinél felsố légúti betegséggel egy idóben, típusos tünetekkel pityriasis rubra pilaris jelentkezett. A diagnózisnak megfelelóen a beteg acitretin kezelést kapott szerény terápiás effektussal, majd methotrexate kezelésben részesült, mely mellett tünetei regressziót mutattak.

\section{SUMMARY}

Pityriasis rubra pilaris is a rare, chronic, idiopathic papulosquamous skin disorder. It occurs commonly in adults however childhood forms are also known. It is characterized by follicular hyperkeratosis, typically orange-colored itching patches with islands of normal skin, progressing into erythroderma. The etiology of pityriasis rubra pilaris is not known. Several cases have been reported with A-hypovitaminosis, upper respiratory tract and HIV infection. Occasional familiar cases have been reported. Due its rare occurence, it is frequently misdiagnosed. The primary treatment includes systemic retinoids, especially acitretin however treatment failure is common.

The authors report a case of a 59-year-old patient, who was diagnosed with pityriasis rubra pilaris and upper respiratory tract infection. He was treated with systemic acitretin with modest response an impressive clearing was shown with the use of methotrexate.

\section{Kulcsszavak: \\ pityriasis rubra pilaris - erythroderma - acitretin - methotrexate}

\section{Key words: \\ pityriasis rubra pilaris - erythroderma - acitretin - methotrexate}

\section{Esetismertetés}

Az 59 éves férfibeteg anamnézisében tonsillectomia és gyógyszeresen kezelt hypertonia szerepel. Emellett a mellkasról cc. basocellulare excisioja történt egy alkalommal. Két hónapja fennálló viszketô bőrtünetekkel jelentkezett ambulanciánkon. Elôször a hajas fejbőrön, majd a törzsön, végül a karjain és combjain észlelte hámló kiütéseit. Elmondása szerint a hospitalizációja előtti héten felső légúti infekció miatt clarithromycin antibiotikum terápiában részesült.

Felvételekor kifejezetten a hajas fejbőrön, az arcon, a törzsön, a felsố végtagokon és elszórtan a combokon 1-2 cm átmérôjú, mérsékelten infiltrált, hámló, erythrodermává konfluáló, narancssárga színú plakkokkat láttunk (1., 2. ábra). Helyenként szigetszerúen
0,5-2 cm-es tünetmentes területek voltak megfigyelhetőek (3. áb$r a$ ). A tenyereken mérsékelt hyperkeratosist észleltünk körömtünetek nélkül (4., 5. ábra), a talpakon diffúz, sárgás keratoderma volt látható (6. ábra). Tekintettel az erythrodermába hajló, kiterjedt bőrtünetekre bőrbiopsziát végeztünk. A szövettani vizsgálata szabályosan rétegzett, megtartott stratum granulosummal bíró hámmal fedett bőrrészletet, a felszínen focalis parakeratosist, a dermisben csekély értágulatot és enyhe kerek sejtes beszúrôdést mutatott (7. ábra). A DIF vizsgálat C3 és IgA pozitív vaszkuláris érintettséget írt le. Az anamnézis, a klinikai kép és a szövettani lelet együttesen az eredetileg felvetett pityriasis rubra pilaris diagnózisát támasztotta alá.

Laboratóriumi vizsgálatok során kisfokban gyorsult süllyedés, emelkedett fehérvérsejt szám és CRP szint mellett jelentôsen emel- 


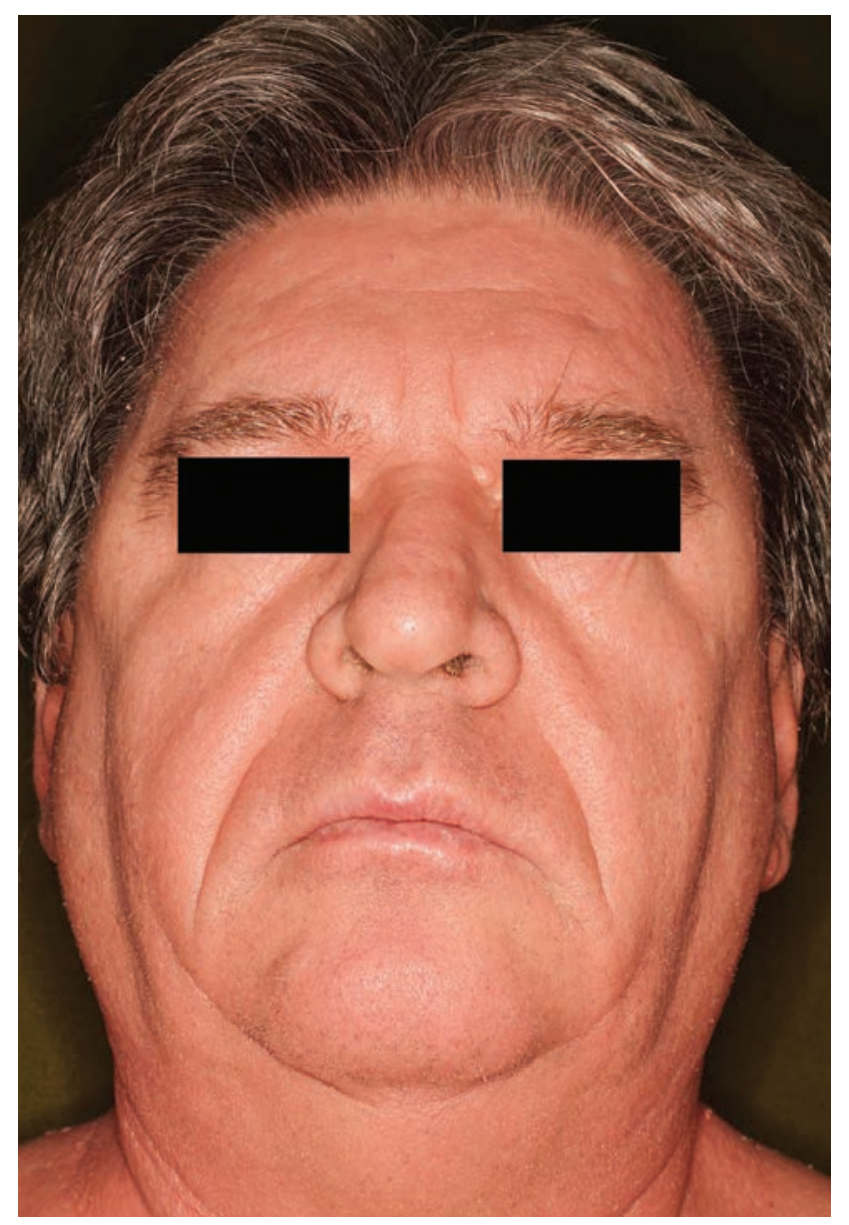

1. ábra

Mérsékelten infiltrált erythema

az arcon

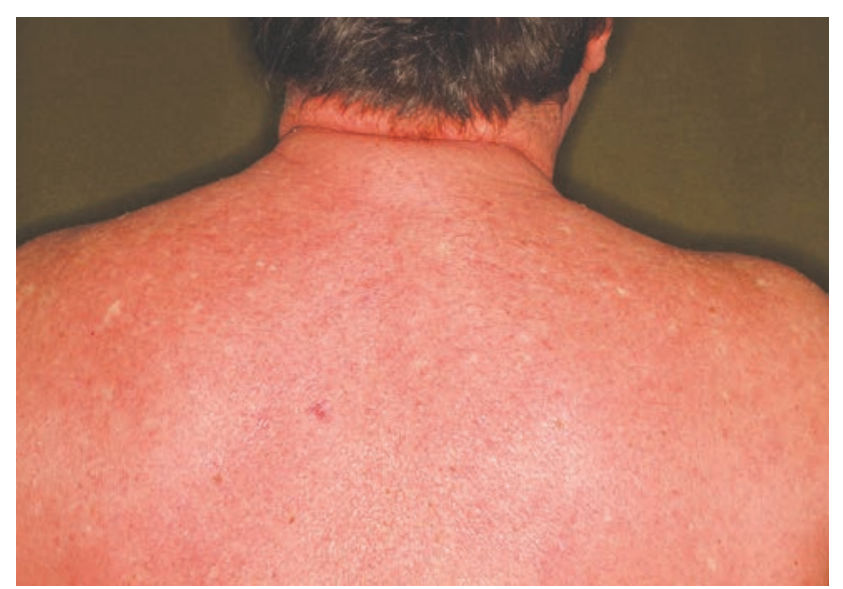

3. ábra

Szigetszerúen elhelyezkedő tünetmentes területek

kedett triglicerid- és húgysavszint, továbbá a hasi, kismedencei UH vizsgálaton steatosis hepatis, pancreatopathia igazolódott, amelyeket a kifejezett obesitas magyarázott.

A klinikai ápolása alatt neoplasiára utaló eltérés nem volt igazolható, mellkasröntgen, tumormarker és széklet Weber vizsgálat negatív eredményt adott. Mellékleletként az immunszerológia ANCA és atípusos ANCA pozitivitást mutatott.

A beteg 2x25 mg dózisban oralis acitretin és 1x25 mg dózisban chloropyramine kezelésben részesült lokális emolliens kezelés mellett. A bevezetett zsírszegény diéta mellett kontroll laborleletében a

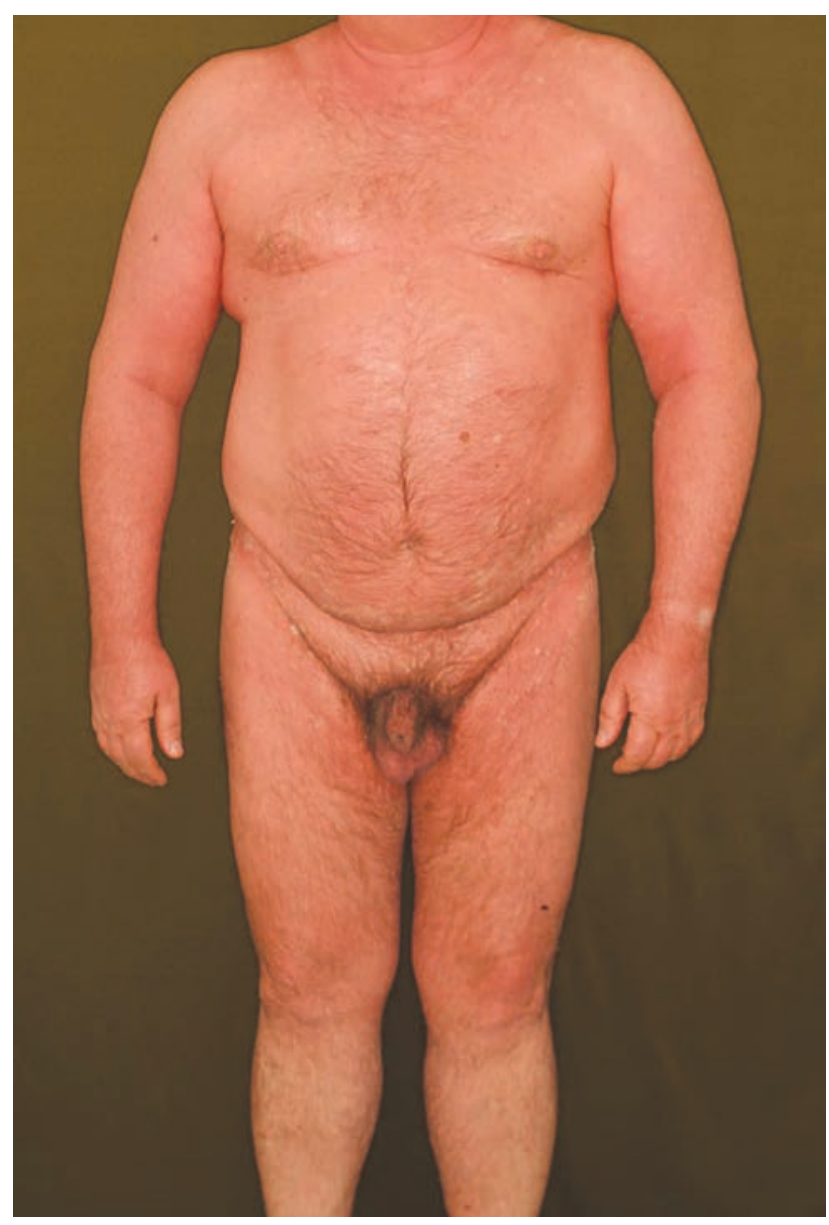

2. ábra

Erythrodermává konfluáló, narancssárga színú, hámló plakkok

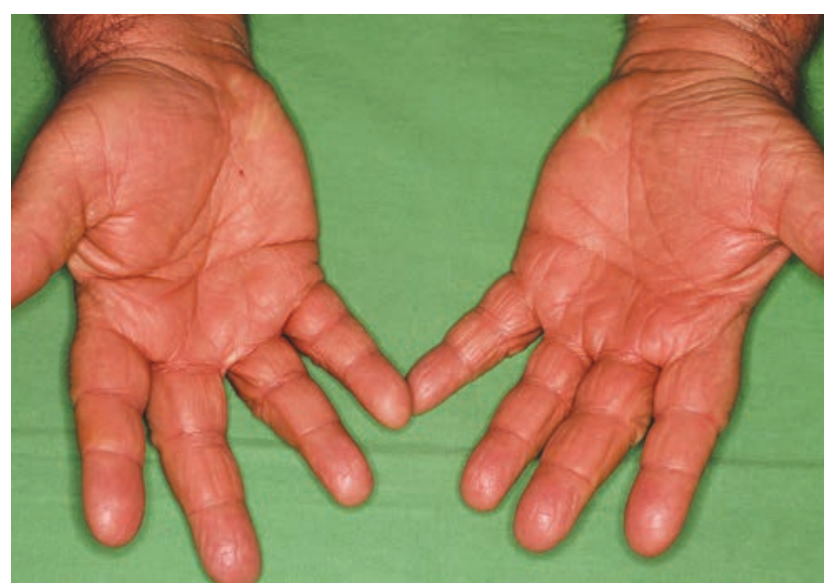

4. ábra

Mérsékelt hyperkeratosis a tenyereken

trigliceridszint csökkenő értéket mutatott. 10 napos hospitalizációt követően a beteget javuló bőrtünetekkel, jó általános állapotban otthonába bocsátottuk. Ambulanter az acitretin kezelést alternáló 25-50 mg dózisra csökkentettük, továbbá az emelkedett lipidszintek miatt fibrát kezelést állítottunk be. Négy hónap kezelést követően továbbra is észleltünk bórtüneteket, ezért a kezelést módosítottuk, az acitretin kezelést felfüggesztettük. Heti $10 \mathrm{mg}$, majd heti $15 \mathrm{mg}$ methotrexate kezelést állítottunk be lokális calcipotriol/betamethasone terápia mellett, és nyolc hónapos kezelést követôen a bôrtünetek teljesen regrediáltak. 


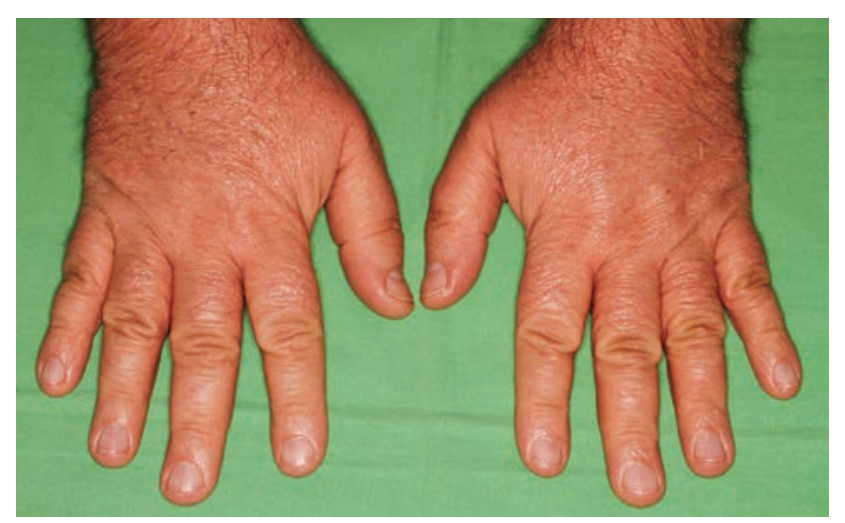

5. ábra

Körömtünetek hiánya

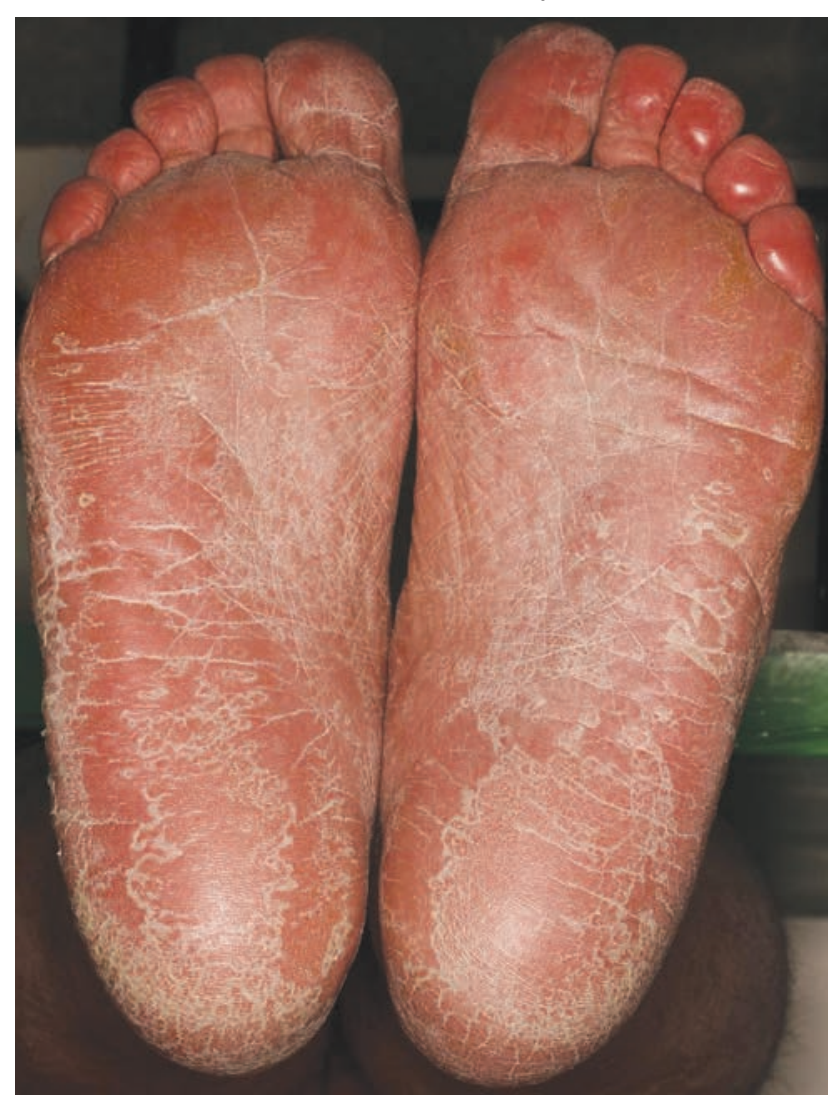

6. ábra

Keratoderma a talpakon

\section{Megbeszélés}

A pityriasis rubra pilarist, mint önálló klinikai entitást először Claudius Tarral írta le 1928-ban, majd Alphonse Devergie 1935-ben. Ritka betegség, incidenciája 1:5000 és 1:50 000 közé tehető, mindkét nem hasonló mértékben érintett $(1,2)$. A betegség idóbeni megjelenése alapján gyermekkori és felnôttkori formák különíthetôk el, melyek csúcsa az elsô és az ötödik évtizedben jelentkezik. Etiológiája és patogenezise nem tisztázott. Hátterében számos ok felvetődik, mint felső légúti Streptococcus fertôzés, amely a szuperantigének szerepére utalhat $(3,4)$, malignus tumor (5), A-hypovitaminosis, esetleg hypothyreosis. A pajzsmirigy hormon elégtelenség esetén a karo-

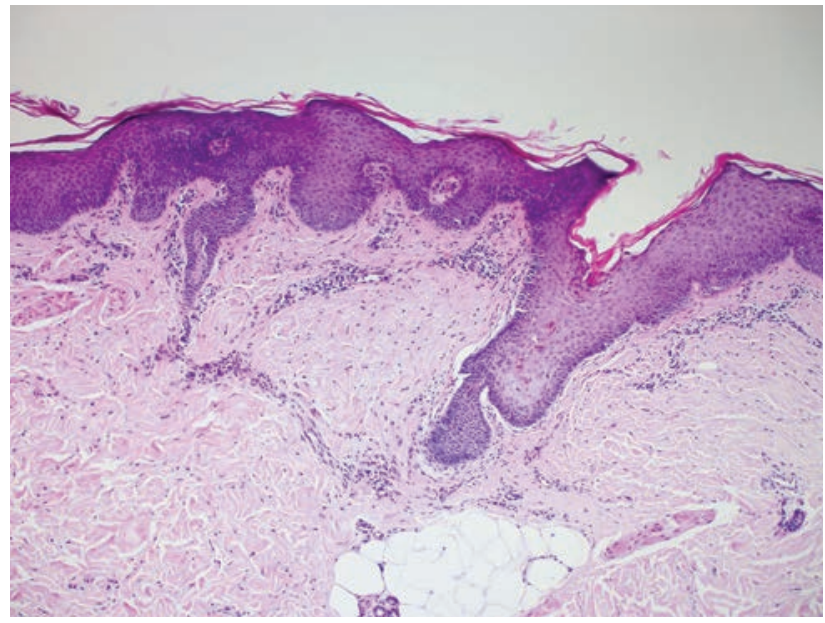

7. ábra

Focalis parakeratosis, megtartott str. granulosum, a dermisben kisfokú értágulat és enyhe, kerek sejtes beszúrődés

tin A-vitaminná alakulása gátolt, ami felelős lehet a bőrtünetek kialakulásáért (6).

Leírtak családi halmozódást is, különösen a gyermekkori formákban, egyes esetekben autoszómális domináns öröklésmenettel, de a legtöbb eset sporadikus (7). Habár a kórképet megfigyelték HIV fertőzött betegek körében, az nem mutat összefüggést az immunszupresszió fokával, a betegség inkább az epidermisben észlelhető keratinizációs zavarral magyarázható (8).

A klinikai lefolyás és tünetek alapján öt csoportját különítjük el: a felnôttkori típus klasszikus és atípusos formáját, a juvenilis típus klasszikus, körülírt és atípusos formáját $(9,10)$. Hatodik típusának a HIV-asszociált variánst tartják (8).

A diagnózis a tünetek kezdetén sokszor nehéz. A diagnosztikában segít a jellegzetes perifollicularis elrendeződésú, erythemás, hyperkeratotikus papulák megléte, amelyek a törzsön caudal felé terjednek, további támpont a plakkokká összeolvadó tünetek narancsvörös színe és az érintett bőrtünetek között élesen elhatárolódó, tünetmentes bőrterületek. Hónapok alatt a progresszió erythrodermáig súlyosbodhat. A körömlemez megvastagodása, subunguális hyperkeratosis, a körömlemez elszíneződése szintén jellemző, azonban a psoriasisban észlelhető olajcsepp tünet és Beau-pontok nem észlelhetôk.

A szövettani vizsgálat a diagnosztikában segíthet, de kiemelendő, hogy a diagnózis döntően nem a szövettanra épül. A szövettani képre a follicularis hyperkeratosis, a vertikalis és horizontális irányultságú para- és ortokeratosis, az erek körüli mérsékelt fokú, kerek sejtes beszûrődés, a stratum granulosum megtartottsága és az enyhén tágult, kanyargós kapillárisok a jellemzők (11).

Jellegzetes a pityriasis rubra pilaris viszonylagos terápia rezisztenciája. A kezelés elsôdleges vonalát a szisztémás retinoidok képzik, ezek közül is elsôsorban az acitretin, $0,5 \mathrm{mg} / \mathrm{ttkg} / \mathrm{nap}$ dózisban $(11,12)$. Szóba jöhet isotretinoin $1 \mathrm{mg} / \mathrm{ttkg} / \mathrm{nap}$, de beszámoltak nagy dózisú, $2 \mathrm{mg} / \mathrm{ttkg} / \mathrm{nap}$ 
alkalmazásáról (13) és alitretinoin 30 mg/nap effektivitásáról is $(14,15)$. A remisszió 14-16 hét kezelés után várható, ezért eredménytelenség esetén a terápiát 3 hónap múlva javasolt módosítani (13).

Egyes esetekben methotrexate 7,5-15 mg/hét, PUVA kezelés hatásos lehet. Az immunszupresszív szerek általában hatástalanok, de terápiarezisztens esetben megkísérelhető ciclosporin adása $300 \mathrm{mg} / \mathrm{nap}$ dózisban $(16,17)$. A szisztémás kortikoszteroid kezelés a mellékhatások miatt inkább nem javasolt. A nagy dózisú A-vitamin (18) vagy stanazolol (19) terápia szintén kis hatékonyságú.

A kezelésre nem reagáló esetekben TNF-alfa gátló adalimumab, infliximab, etanercept adása megkísérelhető, mely 4 hetes kezelést követôen tünetmentességet eredményezhet $(20,21,22,23,24,26)$. IL-12/23 gátló monoklonális ellenanyag ustekinumab $45 \mathrm{mg}$ dózisban szintén hatásos lehet (25).

A lokális kezelésként az irritáló faktorok kiiktatása, a hámlasztó és emolliens kezelés javasolható, de egyes esetekben D3-vitamin-származék calcipotriol, esetleg kortikoszteroidok alkalmazása is szóba jön, amellyel a szisztémás gyógyszerek dózisa csökkenthető.

\section{IRODALOM}

1. Gelmetti C., Schiuma A. A., Cerri D. és mtsai.: Pityriasis rubra pilaris in childhood: a long-term study of 29 cases. Pediatr Dermatol. (1986) 3(6), 446-451.

2. Artik S., Kuhn A., Neumann N. J. és mtsai.: Pityriasis rubra pilaris. Hautarzt. (2004) 55(10), 980-3. [Article in German]

3. Martin K. L., Holland K. E., Lyon V.és mtsai.: An unusual cluster of circumscribed juvenile pityriasis rubra pilariscases. Pediatr Dermatol. (2014) 31(2), 138-145.

4. Möhrenschlager M., Abeck D.: Further clinical evidence for involvement of bacterial superantigens in juvenile pityriasis rubra pilaris (PRP): report of two new cases. Pediatr Dermatol. (2002) 19(6), 569.

5. Remedios I. M., Jensen J. D., Beckum K. és mtsai.: Paraneoplastic pityriasis rubra pilaris as the presenting manifestation of metastatic squamous cell carcinoma. J Drugs Dermatol. (2014) 13(5), 610-612.

6. Franzotti A. M., Avelar J. C., Cardoso T. A. és mtsai.. Pityriasis Rubra Pilar and hypothyroidism. An Bras Dermatol. (2014) 89(3), 497-500.

7. Fuchs-Telem D., Sarig O., van Steensel M. A. és mtsai.: Familial Pityriasis Rubra Pilaris Is Caused by Mutations in CARD14 Am J Hum Genet. (2012) 91(1), 163-170.

8. Miralles E. S., Núñez M., De Las Heras M. E. és mtsai.: Pityriasis rubra pilaris and human immunodeficiency virus infection. $\mathrm{Br}$ J Dermatol. (1995) 133(6), 990-993.
9. Griffiths W. A.: Pityriasis rubra pilaris. Clin Exp Dermatol. (1980) 5(1), 105-112.

10. Griffiths W. A.: Pityriasis rubra pilaris: the problem of its classification. J Am Acad Dermatol. (1992) 26(1), 140-142.

11. Marrouche N., Kurban M., Kibbi A. G. és mtsai.: Pityriasis rubra pilaris: clinicopathological study of 32 cases from Lebanon. Int $\mathrm{J}$ Dermatol. (2014) 53(4), 434-439.

12. Chung P. K., Vergunst C. E., van der Kuip M.: A girl with desquamation of hands and feet. Ned Tijdschr Geneeskd. (2014) 158, A7327. Dutch.

13. Marrouche N., Kurban M., Kibbi A. G. és mtsai.: Pityriasis rubra pilaris: clinicopathological study of 32 cases from Lebanon. Int J Dermatol. (2014) 53(4), 434-439.

14. Amann P. M., Susic M., Glüder F. és mtsai.:Alitretinoin (9-cis retinoic acid) is Effective Against Pityriasis Rubra Pilaris: A Retrospective Clinical Study. Acta Derm Venereol. (2014) Jul 4. doi: 10.2340/00015555-1928.

15. Schmitt L., Inhoff O., Dippel E.: Oral Alitretinoin for the Treatment of Recalcitrant Pityriasis Rubra Pilaris Case Rep Dermatol. (2011) 3(1), 85-88.

16. Iraji F., Siadat A. H.: Pityriasis rubra pilaris following exposure to dolomite. J Res Med Sci. (2013) 18(7), 621-622.

17. Wetzig T., Sticherling M.: Juvenile pityriasis rubra pilaris: successful treatment with ciclosporin. Br J Dermatol. (2003) 149(1), 202-203.

18. Koga M., Koga K., Nakayama J.: A Pediatric Case of Pityriasis Rubra Pilaris Successfully Treated with Low-Dose Vitamin A. Case Rep Dermatol. (2012) 4(2), 170-173.

19. Chan H., Liu F. T., Naguwa S.: A Review of Pityriasis Rubra Pilaris and Rheumatologic Associations. Clin Dev Immunol. (2004) 11(1), 57-60.

20. Bravo E. A., Carrion L., Paucar S. M. és mtsai.: Successful treatment of pityriasis rubra pilaris with adalimumab - case report. Dermatol Online J. (2014) 20(4), 22374.

21. Ruzzetti M., Saraceno R., Carboni I. és mtsai.: Type III juvenile pityriasis rubra pilaris: a successful treatment with infliximab. J Eur Acad Dermatol Venereol. (2008) 22(1), 117-118.

22. Guedes R., Leite L.: Therapeutic hotline. Treatment of pityriasis rubra pilaris with etanercept. Dermatol Ther. (2011) 24(2), 285-286.

23. Sehgal V. N., Srivastava G., Verma P.: Pityriasis rubra pilaris: evolution of challenges in promising treatment options. Skinmed. (2012) 10(1), 18-23.

24. Lin J., Ziring D., Desai S. és mtsai.: TNFa blockade in human diseases: An overview of efficacy and safety. Clin Immunol. (2008) 126(1), 13-30.

25. Di Stefani A., Galluzzo M., Talamonti M. és mtsai.: Long-term ustekinumab treatment for refractory type I pityriasis rubra pilaris J Dermatol Case Rep. (2013) 7(1), 5-9.

26. Eastham A. B., Femia A. N., Qureshi A. és mtsai.: Treatment options for pityriasis rubra pilaris including biologic agents: a retrospective analysis from an academic medical center. JAMA Dermatol. (2014) 150(1), 92-94.

Érkezett: 2015. 10. 05.

Közlésre elfogadva: 2015. 10. 19. 